\title{
Charkaoui: Beyond Anti-Terrorism, Procedural Fairness, and Section 7 of the Charter
}

\section{James Stribopoulos}

\section{The Anti-Terrorism Story}

The Supreme Court of Canada's unanimous decision in Charkaoui v. Canada ${ }^{1}$ has attracted much public attention. Perhaps most newsworthy is the fact that these cases - challenges by three men to provisions of the Immigration and Refugee Protection Act (IRPA) ${ }^{2}$ under which they were detained - represent the first time since September 11, 2001 that the Supreme Court has delivered a defeat to the government in its antiterrorism efforts.

Until Charkaoui, the Court had shown much deference toward the government in this sensitive area. For example, in Suresh $v$. Canada (Minister of Citizenship and Immigration), ${ }^{3}$ the Court left open the possibility that at least in "extraordinary circumstances" it might be permissible for the government to deport a nonresident to a country where she faces a substantial likelihood of torture. Even more important in that case was the Court's endorsement of a deferential approach for reviewing the Minister of Immigration's determination about the likelihood of torture on deportation. Through this move the Court abdicated much responsibility for protecting individual rights to the executive.

Less significant, but still noteworthy, was the Court's decision in Application under s. 83.28 of the Criminal Code (Re), ${ }^{4}$ upholding the controversial anti-terrorism investigative hearings that were hastily added to Canadian law as part the Anti-Terrorism Act. ${ }^{5}$ That legislation was introduced in the fall of 2001, while the Twin Towers were still smouldering.

To many observers, these cases seemed to signal that everything may have indeed changed since 9/11, even in Canada. As in other western democracies, our commitment to longstanding human rights principles suddenly seemed vulnerable when suspected terrorists were the targets.

In Charkaoui, however, the government's honeymoon before the Supreme Court in antiterrorism cases came to an end. For those who followed these cases as they made their way to the Court, the result is not entirely surprising. At the hearing, the judges aggressively challenged government lawyers on the fairness of holding individuals for potentially indefinite periods without providing the detainee, or a lawyer acting on his or her behalf, with an opportunity to review and respond to the actual evidence. It is not surprising, then, that Chief Justice McLachlin's reasons for the Court in Charkaoui recognized the fundamental unfairness of denying people their liberty without affording them a chance to know the case against them, or to respond to that case.

A legislative response from the government, within the one-year grace period granted by the Court, will undoubtedly follow. The most likely solution will be a regime like that in the United Kingdom, where a small group of lawyers with security clearance are charged with the responsibility of responding to the confidential aspects 
of the government's allegations. Any portion of the proceedings that might reveal state secrets will take place in camera, with the targeted individual excluded from the courtroom while the lawyer with security clearance challenges the secret evidence on that person's behalf. Such a scheme would seem to be the minimum demanded by the Charkaoui judgment, in which the Court referred to the English approach with approval. ${ }^{6}$

\section{The Section 7 Story}

Equally important, but not reported in the popular press, is the significance of Charkaoui to the Supreme Court's section 7 Charter of Rights and Freedoms ${ }^{7}$ procedural fairness jurisprudence.

In truth, had the Court wanted to turn a blind eye to the unfairness inherent in the current security certificate system, its existing section 7 precedents gave it much flexibility in choosing a more deferential path. I will momentarily explain the topography of the road not traveled, but for now a more detailed consideration of the Court's analysis is warranted.

In Charkaoui the Court restated many of the key principles that have emerged from its prior section 7 procedural fairness cases. For example, the Court reminded us that what is constitutionally required from a procedural standpoint may vary from one context to another, depending on the individual and state interests that are implicated. ${ }^{8}$

The Court also pointed out something that has too often been forgotten by some western democracies in the post-9/11 world. Simply because the state's interest happens to be national security does not mean that long established principles of fair process should automatically be suspended:

[W] hile administrative constraints associated with the context of national security may inform the analysis on whether a particular process is fundamentally unfair, security concerns cannot be used to excuse procedures that do not conform to fundamental justice at the s. 7 stage of the analysis. If the context makes it impossible to adhere to the principles of fundamental justice in their usual form, adequate substitutes may be found. But the principles must be respected to pass the hurdle of s. 7 . That is the bottom line. ${ }^{9}$

The difficulty with the procedure contemplated by the challenged provisions in the IRPA is that they fail to meet what the Court identifies, for the first time, as the minimum constitutional requirements for fair process:

[I]t comprises the right to a hearing. It requires that the hearing be before an independent and impartial magistrate. It demands a decision by the magistrate on the facts and the law. And it entails the right to know the case put against one, and the right to answer that case. Precisely how these requirements are met will vary with the context. But for s. 7 to be satisfied, each of them must be met in substance. ${ }^{10}$

Here, the regime fell down because it did not respect the final two requirements: the right to know the case one is facing and the right to answer that case. Nor did it provide an adequate substitute for those rights, for example by employing a system like that in the United Kingdom, as mentioned above.

This was so, even though the IRPA requires the reviewing judge to provide the affected individual with a summary of the information furnished by the government so as to enable him to be reasonably informed of the circumstances giving rise to the certificate. The person could then use that summary to argue that the security certificate should not have been issued. The summary, however, cannot include anything that would, in the opinion of the judge, be injurious to national security or to the safety of any person.

For the Court, the summary, and the chance to respond to it, were not enough to comply with section 7 . The difficulty with this, said the Court, was that:

[i]t could mean that the judge may be required to decide the case, wholly or in part, on the basis of information that the named person and his or her counsel never see. The person may know nothing of the case to meet, and although technically afforded an opportunity to 
be heard, may be left in a position of having no idea as to what needs to be said. ${ }^{11}$

Given its conclusion that the scheme is inherently unfair and therefore fundamentally unjust, the Court had little difficulty concluding that the resulting constitutional violation could not be reasonably justified in a free and democratic society.

The Court's analysis seems clear and compelling. The main difficulty with its approach is that it is hard to reconcile with its own prior judgments. Before Charkaoui, the Supreme Court had consistently rejected the idea that fair process necessitated full access to all relevant information and an opportunity to address the decision-maker on the merits. ${ }^{12}$

For example, just last year in R. v. Rodgers, ${ }^{13}$ the Court rejected a section 7 challenge to section 487.055 of the Criminal Code. That provision allows for the issuance of a court order, on ex parte bases, for the collection of DNA samples from already convicted and incarcerated offenders. In other words, the Court upheld a scheme whereby an individual's DNA could be taken without prior notice or an opportunity to address the judge who is asked to issue the order. This procedure was upheld, even though there was no compelling state interest necessitating an ex parte process. Remember, in that context, those affected are already in custody and therefore unable to flee the jurisdiction if given notice and a chance to be heard. In addition, the DNA of these offenders was not something that could be destroyed or concealed, such that the need for stealth on the part of the government could be justified.

Even more significantly, in Chiarelli v. Canada (Minister of Employment and Immigration), ${ }^{14}$ the Supreme Court upheld the impugned provisions. Chiarelli was a case involving a landed immigrant who was subject to an immigration removal certificate for alleged connections to organized crime under a legislative scheme that was strikingly similar to that at issue in Charkaoui. It did so, even though at the time, the legislation required only that a summary of the evidence relied on be disclosed to the individual whose deportation was being sought.
The challenge in Charkaoui was how to distinguish these prior judgments. The Court did so by emphasizing the stakes involved in this case:

Where limited disclosure or ex parte hearings have been found to satisfy the principles of fundamental justice, the intrusion on liberty and security has typically been less serious than that effected by the IRPA .... It is one thing to deprive a person of full information where fingerprinting is at stake, and quite another to deny him or her information where the consequences are removal from the country or indefinite detention. Moreover, even in the less intrusive situations, courts have insisted that disclosure be as specific and complete as possible. $^{15}$

Of course, conspicuously absent from this paragraph is any attempt by the Court to distinguish the circumstances in Chiarelli from those in Charkaoui. This is not entirely surprising. The cases are difficult to distinguish, remembering that both involved the permanent removal of individuals from Canada.

Also refreshingly absent from Charkaoui, no doubt because of the ultimate result, is the rhetorical device that the Court has often offered up whenever a procedural fairness claim is denied - that the principles of fundamental justice require only fairness, not "the most favourable procedures that could possibly be imagined."16

What I hope is apparent by this point is that there has been much imprecision in the Court's prior section 7 jurisprudence regarding what procedural fairness demands. As a result, it would have been very easy for the Court to rationalize upholding the sections at issue in this case.

That said, I do not mean to suggest that the decision in Charkoui should not be celebrated. It is profoundly unfair that someone could be arrested, held in custody, and ultimately deported based entirely on evidence that neither they nor their legal representative is permitted to see and consequently answer.

My complaint is much more general, extending well beyond the context of Canada's 
anti-terrorism efforts. In short, that the judgment fails to provide much guidance on when the implications for liberty or security of the person will be sufficiently great that notice, full disclosure (at least to the individual's legal representative) and an opportunity to be heard will be constitutionally mandated.

The standards for engaging liberty or security of the person under section 7 are not low. Only serious interferences with individual autonomy qualify. ${ }^{17}$ Therefore, simply suggesting, as the Court does in Charkaoui, that when the stakes are great enough the demands of procedural fairness increase, tells us very little.

By choosing the path it did, the Court carefully avoided acknowledging any limitation in its prior section 7 decisions involving procedural fairness claims. In the process, it missed an important opportunity to offer a more coherent account of how to go about measuring what due process demands in any given context.

You may be wondering what I have in mind.

\section{An alternative approach}

Ultimately, "how much due process?" is a question that necessitates an analysis that begins from the perspective of the individual whose interests are affected. The concrete impact on that individual's liberty or security of the person must be considered against the state's more abstract and competing interest(s). In measuring how much due process to provide, the most sensible question is to ask is: how much can the state reasonably afford? Here, I do not mean simply monetary cost, although that is undoubtedly a legitimate consideration. Rather, what I have in mind are the potential drawbacks for the interests of the state if more due process is given.

Returning to the circumstances in Charkaoui, the individual interests involved in this case are significant. The issuance of a security certificate leads to arrest, detention, and, ultimately, deportation. Weighted on the other end of the scale are the legitimate interests of the state, which would seem to be twofold here: first, streamlining security certificate procedures so that individuals who do pose a threat to the safety of Canada are removed from the country as quickly as possible; and, second, ensuring that sensitive state secrets remain confidential. Both state objectives are very important.

Once the competing interests are identified and placed on the scale in this way the question to be asked is this: if more due process is provided, would the state's legitimate objectives be undermined? If the answer to that question is "no," as it is in Charkaoui, then the amount of procedural fairness being provided should be increased until the balancing point is reached. Here, as the Court correctly concluded, the interests of the state could be more than adequately met through a system of security cleared counsel who could have full access to the evidence and could therefore meaningfully challenge the government's case.

In other words, the existing regime is fundamentally unjust because it subordinates the interests of the individual to those of the state in circumstances where there is no appreciable benefit to state interests. Unfortunately, a more coherent account of how to go about determining how much due process section 7 of the Charter demands will need to await some future case.

\section{Notes}

* Assistant Professor, Osgoode Hall Law School, York University, e-mail: Jstribopoulos@osgoode. yorku.ca.

1 Charkaoui v. Canada (Citizenship and Immigration), 2007 SCC 9 (CanLII) [Charkaoui].

2 S.C. 2001, c. 27, ss. 33. 77-85.

3 Suresh v. Canada (Minister of Citizenship and Immigration), 2002 SCC 1, [2002] 1 S.C.R. 3. (CanLII).

4 Application under s. 83.28 of the Criminal Code (Re), 2004 SCC 42, [2004] 2 S.C.R. 248 (CanLII).

5 Anti-terrorism Act, S.C. 2001, C. 41.

6 Supra note 1 at para. 80.

7 Canadian Charter of Rights and Freedoms, Part I of the Constitution Act, 1982, being Schedule B to the Canada Act 1982 (U.K.), 1982, c. 11 (CanLII).

8 Charkaoui, supra note 1 at para. 20.

$9 \quad$ Ibid. at para. 23.

10 Ibid. at para. 29 [emphasis in original]. 
$11 \quad$ Ibid. at para. 55.

12 See Goodis v. Ontario (Ministry of Correctional Services), 2006 SCC 31, [2006] 2 S.C.R. 32 at para. 21 (CanLII); R. v. Rodgers, 2006 SCC 15, [2006] 1 S.C.R. 554 at para. 51-52 (CanLII); Ruby v. Canada (Solicitor General), 2002 SCC 75, [2002] 4 S.C.R. 3 at para. 38-44 (CanLII) [Ruby]; and Chiarelli v. Canada (Minister of Employment and Immigration), [1992] 1 S.C.R. 711 at 744 (CanLII) [Chiarelli].

13 R. v. Rodgers, 2006 SCC 15, [2006] 1 S.C.R. 554 (CanLII).

14 Chiarelli, supra note 10.

15 Charkaoui, supra note 1 at para. 60.

16 R. v. Lyons, [1987] 2 S.C.R. 309 (CanLII). See also Ruby, supra note 10 at para. 46; Winnipeg Child and Family Services v. K.L.W., 2000 SCC 48, [2000] 2 S.C.R. 519 at para. 130 (CanLII); $R$. v. Rose, [1998] 3 S.C.R. 262 at para. 99 (CanLII); B. (R.) v. Children's Aid Society of Metropolitan Toronto, [1995] 1 S.C.R. 315 at para. 101 (CanLII); R. v. Harrer, [1995] 3 S.C.R. 562 at 573, Justice La Forest (CanLII); R. v. Finta, [1994] 1 S.C.R. 701 at 744, Justice La Forest (CanLII); R. v. Bartle, [1994] 3 S.C.R. 173 at 225, Justice L'Heureux-Dubé (CanLII); Dehghani v. Canada (Minister of Employment and Immigration), [1993] 1 S.C.R. 1053 at 1077, Justice Iacobucci (CanLII); and Thomson Newspapers Ltd. $v$. Canada (Director of Investigation and Research, Restrictive Trade Practices Commission), [1990] 1 S.C.R. 425 at 540, Justice La Forest (CanLII).

17 See Blencoe v. British Columbia Human Rights Commission, 2000 SCC 44, [2000] 2 S.C.R. 307 (CanLII), the Court's most recent and definitive pronouncement on when "liberty" or "security of the person" are implicated by state action. 